\title{
The value proposition of case reports
}

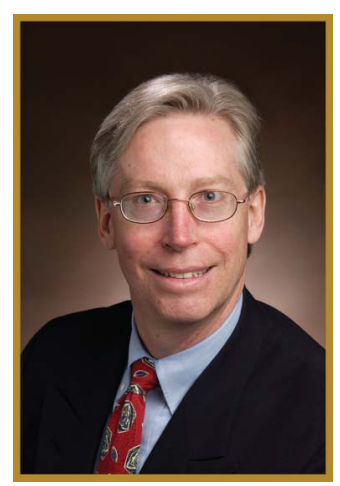

\section{Novelty, pedagogy, anecdotal aggregation, humanity}

S ome in scientific and academic circles downplay the importance of case reports, but clinical practitioners understand their value. Editors of medical science journals acknowledge the popularity of case reports, but most dedicate little space to them, citing a deleterious effect on the journal's metrics, most notably the Impact Factor.

Neurology ${ }^{\circledR}$ Clinical Practice (NCP) strives to provide our readers with succinct point-of-care content they can use on a daily basis to improve patient outcomes. In this context we value peer-reviewed case reports because bedside practice of neurology depends heavily on careful observation, history-taking, and diagnostic acumen of the clinician. In recognition of their value, we are pleased to dedicate this issue to case reports, and inaugurate the inclusion of a "Practical implications" statement for full cases.

Case reports have played a distinguished role in furthering the research and practice of medicine and offer discoveries of unanticipated associations or unexpected treatment effects and disease features. ${ }^{1,2}$ Cases in point: In early 2005, 3 cases of natalizumab-associated progressive multifocal leukoencephalopathy caused by reactivation of the JC virus were reported to the drug maker and then featured in a single issue of the New England Journal of Medicine. ${ }^{3-5}$ These case reports had a truly profound effect-temporary withdrawal of the drug from the market, development of a JC virus serologic marker, and a host of regulatory, insurance, and behavioral changes in the neurologic and pharmaceutical communities. Correspondence published in $N C P^{6}$ regarding an article that discusses the ethics of reporting postmarketing adverse drug reactions ${ }^{7}$ highlights the role of case reports in providing a venue for discovery and disclosure.

Case reports are a touchstone-they convey concepts and content, but also promote critical thinking and humanize disease entities. Case reports are a proven, effective 
communication tool among busy practitioners and may inform personalization of treatments in clinical practice. ${ }^{8}$

We welcome reader feedback on this special issue and the case reports herein.
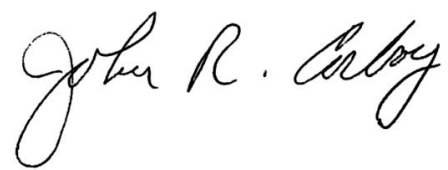

\section{John R. Corboy, MD, FAAN}

\section{REFERENCES}

1. Swiontkowski MF, Tolo VT. The case report redefined with JBJS case connector. J Bone Joint Surg Am 2013;95:97.

2. Bhattacharrya S, Miller J, Ropper AH. The case for case reports. Ann Neurol 2014;76:484-486.

3. Van Assche G, Van Ranst M, Sciot R, et al. Progressive multifocal leukoencephalopathy after natalizumab therapy for Crohn's disease. N Engl J Med 2005;353:362-368.

4. Kleinschmidt-DeMasters BK, Tyler KL. Progressive multifocal leukoencephalopathy complicating treatment with natalizumab and interferon beta-1a for multiple sclerosis. N Engl J Med 2005;353: 369-374.

5. Langer-Gould A, Atlas SW, Green AJ, Bollen AW, Pelletier D. Progressive multifocal leukoencephalopathy in a patient treated with natalizumab. N Engl J Med 2005;353:375-381.

6. Shubhakar K, Khichar RJ, Klein E, Bourdette D. postmarketing adverse drug reactions: a duty to report? Neurol Clin Pract 2014;4:2-3.

7. Klein E, Bourdette D. Postmarketing adverse drug reactions: a duty to report? Neurol Clin Pract 2013; 3:288-294.

8. Alderazi YJ, Bomprezzi R. Are randomized, blind clinical trials enough to guide individualized decisions for patients with neurologic diseases? Neurol Clin Pract 2014;4:319-328.

\section{Special Case Reports Issue - Feedback Requested!}

We are pleased to dedicate the December 2014 issue of Neurology ${ }^{\circledR}$ Clinical Practice to Case Reports. Please complete our survey to let us know what you think! 


\section{Neurology ${ }^{\circ}$ Clinical Practice}

The value proposition of case reports: Novelty, pedagogy, anecdotal aggregation, humanity

Neurol Clin Pract 2014;4;465-466 Published Online before print November 12, 2014

DOI 10.1212/CPJ.0000000000000090

This information is current as of November 12, 2014

$\begin{array}{ll}\begin{array}{l}\text { Updated Information \& } \\ \text { Services }\end{array} & \begin{array}{l}\text { including high resolution figures, can be found at: } \\ \text { http://cp.neurology.org/content/4/6/465.full.html }\end{array} \\ \text { References } & \text { This article cites } 8 \text { articles, } 4 \text { of which you can access for free at: } \\ \text { http://cp.neurology.org/content/4/6/465.full.html\#\#ref-list-1 } & \text { Information about reproducing this article in parts (figures,tables) or in } \\ \text { Permissions \& Licensing } & \text { its entirety can be found online at: } \\ \text { http://cp.neurology.org/misc/about.xhtml\#permissions } & \\ \text { Information about ordering reprints can be found online: } \\ \text { http://cp.neurology.org/misc/addir.xhtml\#reprintsus }\end{array}$

Neurol Clin Pract is an official journal of the American Academy of Neurology. Published continuously since 2011, it is now a bimonthly with 6 issues per year. Copyright (C) 2014 American Academy of Neurology. All rights reserved. Print ISSN: 2163-0402. Online ISSN: 2163-0933.

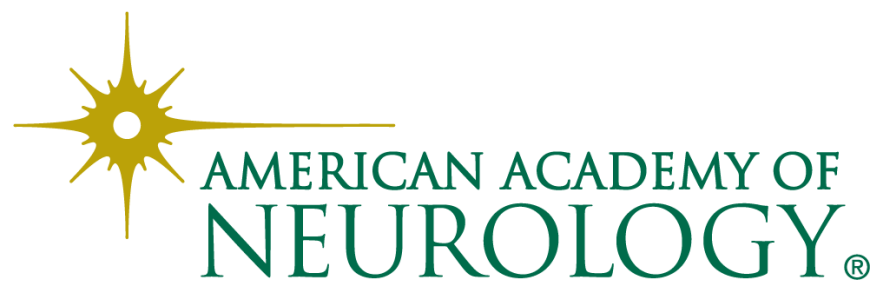

